\title{
Growth in a time of external imbalances*
}

\author{
Mariam Camarero \\ University Jaume I and \\ INTECO
}

\author{
Jesús Peiró-Palomino
}

University Jaume I and INTECO

\author{
Cecilio Tamarit
}

University of Valencia and INTECO

\begin{abstract}
Globalization and financial integration have increased in the last three decades giving rise to cumulated large external imbalances. The question we address in this paper is whether economic growth can be affected by these external imbalances. We estimate an augmented growth equation with the external stock position of the countries measured by the net foreign asset position. Unlike previous literature, we use non- parametric methods that capture nonlinearities and heterogeneity, and apply them to a sample that includes 106 developed and developing countries for the period 1983-2011. Contrary to the neoclassical theory, we find that improvements in the external position foster growth. However, our results are in line with current theoretical contributions, suggesting that the effect of the net foreign asset position on growth is heterogeneous across countries and that there is no universal mechanism. In particular, we find that the impact depends on characteristics of the countries such as institutional quality, openness and financial development.
\end{abstract}

Keywords: Economic growth; net foreign assets; parameter heterogeneity

JEL classification: C14; F34; 047

Communications to: Jesús Peiró-Palomino, Department of Economics, University Jaume I, Campus del Riu Sec, 12071 Castelló de la Plana, Spain. Tel: +34 964728592, e-mail: peiroj@uji.es

${ }^{*}$ The authors are members of the INTECO Joint Reseach Unit UJI-UV, funded by Generalitat Valenciana, Prometeo Project PROMETEOII/2014/053. Jesús Peiró-Palomino and Mariam Camarero acknowledge the financial support of the University Jaume I (UJI-B2017-33). Jesús Peiró-Palomino acknowledges the financial support of research project (ECO2017-85746-P). Cecilio Tamarit and Mariam Camarero acknowledge the financial support of research project (ECO2017-83255-C3-3-P), Programa Estatal de Fomento de la Investigación Científica y Técnica de Excelencia, Subprograma Estatal de Generación de Conocimiento, Ministerio de Economía, Industria y Competitividad (MINEIC), Gobierno de España and FEDER (European Regional Development Fund). This paper has also benefited from the remarks of the participants in several conferences, such as the 5th ISCEF, the XIV INTECO Workshop, the CFE-CMStatistics 2017 and the IAAE 2017. The authors are indebted to the comments and suggestions of the Journal editor, Sushanta Mallick, and three anonymous referees. All remaining errors are ours 


\section{Introduction}

Financial globalization has taken the form of enormous capital flows giving rise to increasing external imbalances, both in flow and stock terms. However, while global current account ("flow") imbalances have narrowed significantly since their peak in 2006, these reductions have been contemporaneous to increasing stock imbalances. The question is whether these developments in stock terms may threaten economic growth (IMF, 2014; Catão and Milesi-Ferretti, 2014).

The net foreign assets ratio relative to GDP (NFA henceforth) is generally accepted as a measure of the cumulated net external position of a country. ${ }^{1}$ This variable is obtained as the value of assets owned by domestic residents held abroad minus the value of domestic liabilities to the rest of the world. A country, therefore, can be either a net creditor $(N F A>0)$ or a net debtor $(N F A<0)$. According to standard neoclassical theory, a worsening of the NFA position would be positively related to per capita income growth as global capital flows into higher productivity countries. Yet, with globalization, the presence of financial frictions may challenge this relationship. One key issue, according to Broner and Ventura (2016) and Forbes et al. (2017) is the amount of international risk sharing and its costs. In fact, recent work finds that financial frictions can cause higher growth in low income countries to become associated with current account surpluses, the so-called Lucas paradox or "allocation puzzle"” (Gourinchas and Jeanne, 2013; Mendoza et al., 2009).

Therefore, in order to address these controversies, in this paper we contribute to former literature in several respects. First, we not only assess the role of net external positions on growth, but also attempt to unravel how the process of globalization might influence this relationship. ${ }^{3}$ Second, we identify sources of heterogeneity in the NFAgrowth link. In that regard, whereas previous literature mostly rely on parametric estimations, we apply non-parametric kernel regressions. Empirical contributions in the literature of economic growth and related fields using these techniques are on the rise, 4 since they are data-driven methods providing a totally flexible framework that allows for non-linearities and parameter heterogeneity, both across countries and over time. Following Broner and Ventura (2016), we assess whether the sign and the magnitude of the relationship is similar in countries sharing common attributes, such as external imbalances (creditor or debtor positions), geographical location, degree of development, institutional quality, financial development or commercial openness. ${ }^{5}$ As Alfaro et al. (2008) point out,

${ }^{1}$ The choice of this variable for the analysis is extensively discussed in Section 4.

2 These results are not exempt from criticism; for example, Alfaro et al. (2014) find that this paradox may not apply to private flows and Ferrero (2010) considers that other factors, such as demography can also affect the sign and strength of this relationship, as capital would flow toward relatively young and rapidly growing countries.

${ }^{3}$ See the related literature, for instance Prasad et al. (2007), Ayhan Kose et al. (2009) or Obstfeld (2009).

4 See, for instance, Henderson et al. (2012b, 2013); Sanso-Navarro and Vera-Cabello (2016); Peiró-Palomino (2016, 2017).

${ }^{5}$ GDP per capita growth has been explained by a large number of theories. It is common practice to consider 
institutional quality has played a key role in shaping the direction of capital flows. Third, unlike previous evidence, mainly focused on developing countries and with non-concluding results (Pattillo et al., 2011), this study extends the analysis of the impact of the net external position on growth to both developed and developing nations using data from the Penn World Tables (PWT) 8.1 and the updated Lane and Milesi-Ferretti (2001) database, covering the period 1983-2011.

We find a preponderant positive coefficient for the NFA-growth nexus, which means that growth is constrained in debtor countries while the opposite holds for creditors. However, after allowing for non-linearities and parameter heterogeneity in our models, our findings also suggest that the impact varies across countries and over time. In particular, the relationship is affected by country-specific factors such as the depth of financial development, commercial openness and the quality of formal institutions.

The remainder of the paper is organized as follows: Section 2 reviews previous theoretical and empirical literature on the external imbalances-growth nexus, starting from the neoclassical growth model up to more recent theories that explain some paradoxical stylized facts related to external imbalances. In Section 3 we account for the methodology. The specified models and data are introduced in Section 4, whereas the main empirical results are presented in Section 5. Finally, Section 6 concludes.

\section{Theoretical review and related empirical literature}

The neoclassical model has been considered the standard workhorse framework for the analysis of financial integration and its consequences. In this model, capital moves from countries with low autarky returns to those with high autarky returns. ${ }^{6}$ Moreover, each country's autarky returns are determined by two factors: capital abundance/scarcity and growth prospects in the long-run. The main prediction of this theory is that countries export capital when this factor is relatively abundant, in a similar fashion as the principles of comparative advantage.

The fulfillment of the neoclassical theory would imply a negative relationship between growth and the net foreign position of a country: this means that creditor countries would reduce their growth rate whereas debtor countries will increase it thanks to the contribution of external resources. Moreover, according to this, the most advanced economies would grow at a lower rate than less affluent countries leading to a catching-up process.

Empirical evidence, however, does not always support the neoclassical theory and the macroeconomic effects of the increasing globalization in terms of growth and convergence are far from being conclusive. ${ }^{7}$ For example, the US has been importing capital since 1982, coming from emerging economies, a phenomenon that has been called

\footnotetext{
the Solow variables as the baseline model, where variables from other theories such as demography, policy, geography, fractionalisation, institutions or financial development are added.

6 See Gourinchas and Rey (2014) for a detailed description of the main elements of the model.

7 For a survey on the literature about the relationship between financial development and economic growth see Levine (2005).
} 
the allocation puzzle by Gourinchas and Jeanne (2013). Moreover, productivity growth and net capital inflows are not always positively related, as pointed out by Prasad et al. (2007). Therefore, newer theories or extensions of the neoclassical model have tried to explain these puzzling facts and the pattern of external imbalances. Their underpinnings were laid out by the maximizing models that took over the field of international economics in the early 1980s: i) the intertemporal approach (IA) to the current account; and ii) the openeconomy versions of the Real Business Cycle (RBC). ${ }^{8}$ Both share the same purpose: to analyze capital flows and their effects on the macroeconomy. However, they make opposite assumptions regarding the costs of international risk sharing. Whereas the IA to the current account considers these costs prohibitive, for the RBC they are negligible. From an empirical point of view, the IA models work for industrial countries and the RBC fail, as they predict more risk sharing than observed. Neither of the two models works empirically for emerging countries, and that may explain why the attention of alternative proposals has concentrated on developing economies.

Another more recent extension of the neoclassical model was a new class of models emphasizing the role of strategic default on foreign debt, called the sovereign risk models (Aguiar and Amador, 2014). These models point to the existence of a threshold or turning point in the degree of external leverage where the initial positive effect of the external imbalances on growth becomes negative. A similar perspective, although based on the role of the financial system and credit, has been adopted by Arcand et al. (2015). Also in this case, up to a threshold, there is no positive correlation between financial depth and economic growth.

All in all, strategic default models make the same predictions as the IA models. They reduce the size of the effects, but do not change their nature. Therefore, it was necessary to find alternative theories that could better explain the nature of external imbalances and their effects across countries. Accordingly, the focus shifted from macroeconomic variables to microeconomic frictions in financial markets.

According to the standard neoclassical theory the sign of the gap between the hypothetical autarky interest rate and world rates indicates whether a country will be a net recipient or exporter of capital. However, that sign depends not only on the marginal productivity of domestic investment, but also on saving patterns ${ }^{9}$ In the same vein, Lucas (1990) wondered why countries with very low capital-to-labour ratios do not exhibit sometimes high autarky interest rates; he found that a possible reason was the scarcity of human capital along with the abundant physical one. On the contrary, weak institutions and property rights can lower the perceived productivity of investment, as highlighted by Alfaro et al. (2008). Even when the return to investment is potentially high, financial market imperfections can reduce the autarky interest rate, limiting investment and driving saving abroad, as in the models of Caballero et al. (2008) and Mendoza et al. (2009).

\footnotetext{
${ }^{8}$ See Obstfeld and Rogoff (1996) and Blanchard et al. (2016) for a description of both models.

9 Saving patterns can reflect, among others, the evolution of variables such as demography i.e. countries with aging populations run external surpluses (Ferrero, 2010); cultural characteristics, as some countries show a bias to higher precautionary demand for savings (Aiyagari, 1994), and specific policies, i.e. specialization in labour or capital-intensive products may determine that a country becomes capital exporter or importer Antràs and Caballero, 2009; Jin, 2012).
} 
These facts reverse the predictions of the IA models regarding the pattern of capital flows, so that financial liberalization can reduce investment and growth in developing capital-scarce countries swapping risky, high-return assets for safe, low-return assets in developed countries. This is a promising approach to explain why capital flows towards countries that are already rich and have developed financial markets (financial depth effect). Following this approach, Broner and Ventura (2016) develop a modern theory of financial globalization. In their model they aim at reconciling the different stylized facts present in the literature of the effects derived from financial globalization. The model stresses the role of imperfect enforcement of domestic debts and the interactions between domestic and foreign debt. According to these authors, the outcome in terms of growth of the external position of a country involved in a process of financial globalization will depend on the initial level of development together with other fundamentals, namely the level of productivity, domestic savings, the quality of institutions and the evolution of the market sentiment.

Within this framework the effects of financial globalization are heterogeneous. This is in sharp contrast to the representative-agent benchmark models, where financial globalization always leads to capital inflows in developing countries. In their model, a country that liberalizes is subject to three different possible outcomes in terms of capital flows and growth depending on the level of development: i) at low levels of development, the country imports capital and growth accelerates (the capital-flight effect is weak because domestic financial markets are very shallow and globalization still results in net capital inflows); ii) at intermediate levels of development, financial globalization leads to net capital outflows and slows down growth (the domestic capital flight effect prevails) and iii) at high levels of development, we are under multiple equilibria. There will be capital imports and higher growth under optimist expectations and capital exports and lower growth under pessimism, giving rise to recurrent cycles of high and low-growth periods. Therefore, financial globalization will have heterogeneous effects depending on the country's characteristics.

Concerning the empirics, as pointed out by Checherita-Westphal and Rother (2012), the literature has focused until recently on the role of the external debt in developing countries and found this to be a key predictor of financial crises in emerging economies. ${ }^{10}$ Thus, while Schclarek (2004) claims that they have a linear relationship, some other studies such as Pattillo et al. (2011), Smyth and Hsing (1995) and Cohen (1997) argue that they follow a non-linear pattern. A recent strand of literature aims at ascertaining whether and to what extent the external debt-growth nexus depends on country-specific characteristics, such as the quality of their policies and institutions (see Catão and Milesi-Ferretti, 2014), obtaining heterogeneous results across countries and time periods. ${ }^{11}$

\footnotetext{
10 Evidence on this point is provided by Hsing (1995); Cohen (1997); Pattillo et al. (2011); Clements et al. (2003); Schclarek (2004); Bussière and Fratzscher (2006); Catão and Milesi-Ferretti (2014); Bussière (2013), to name a few.

11 Presbitero (2008) found evidence of a threshold laying in a range from $10 \%$ to $30 \%$ for poor countries. Imbs and Ranciere (2005) confirmed a 60\% level result using non-parametric methods. Pattillo et al. (2011) also found evidence of a hump-shaped effect of debt overhang using regressions augmented with debt dummy variables for the threshold between $35-40 \%$ of GDP.
} 
Up to now, however, empirical evidence is far from being conclusive and calls for further research. Our hypothesis is that the existence of a positive or negative relationship between NFA and growth will depend critically on the stage of development of the country, and country-specific fundamentals such as the degree of development of the domestic financial market, ${ }^{12}$ the rate of saving, the productivity levels or the institutional quality, which may affect the investor's expectations and trigger sharp changes in financial flows, investment and growth. The econometric approach adopted allows us to uncover these elements stressing its relative importance with a high degree of detail.

We explore the nexus NFA-growth by adopting an approach that estimates an augmented growth equation. In this equation, in addition to domestic investment and human capital we also account for foreign capital, as in Alfaro et al. (2008), so that agents can borrow internationally. In order to encompass the different theoretical approaches described above, we will include additional controls, such as financial development, the degree of openness, the world region, and the quality of institutions. Thus, we will account for international capital imperfections, sovereign risk and asymmetric information. We argue that there is heterogeneity in the effect that the process of world financial integration or globalization has had on the different countries and on the distribution of capital flows internationally. Moreover, we posit that this process has generated imbalances and, in some cases, this has been detrimental to growth.

\section{Methodology}

\subsection{Non-parametric kernel regressions}

The external net position-growth nexus is assessed by means of non-parametric kernel regressions. However, as a preliminary approach, we also run parametric (OLS) estimations, expressed as:

$$
Y_{i}=\beta_{0}+\sum_{j=1}^{T} \beta_{j} Z_{j i}+\varepsilon_{i}, \quad i=1,2, \ldots n
$$

where $Y_{i}$ is the average growth rate of GDP per capita in real terms for country $i, Z$ is a vector of $T$ regressors, $\beta_{0}$ and $\beta_{j}$ are parameters and $\varepsilon_{i}$ is the disturbance term.

Parametric estimations usually provide interesting insights, but they are quite restrictive in terms of assumptions to obtain reliable estimates. Oppositely, non-parametric regressions, data-driven in nature, are totally flexible. Let us consider the non-parametric counterpart to Equation (1), given by:

$$
Y_{i}=m\left(Z_{i}\right)+\varepsilon_{i}, \quad i=1,2, \ldots n
$$

\footnotetext{
12 The existence of a threshold in the financial development-growth nexus has also been emphasized, among others, by Cecchetti and Kharroubi (2012), Arcand et al. (2015) and Beck et al. (2014).
} 
where all the elements other than $m($.$) are equivalent to Equation (1) and m($. stands for a data-driven function between the response variable and the regressors.

In order to estimate Equation (2) we employ the local-linear least squares (LLLS) estimator, introduced by Racine and Li (2004). The estimator computes a weighted leastsquares regression around each point $z_{i}$ with no assumptions on the functional form or a distribution of the error term (Li and Racine, 2007). A kernel function and a bandwidth vector establish the weights, with those observations near $z_{i}$ receiving more weight. The functional form of $m($.$) is obtained linking all the estimated points. Formally, let us$ reconsider Equation (2). A first-order Taylor expansion for the continuous variables, denoted as $z^{c}$, yields:

$$
Y_{i} \approx m(z)+\left(z_{i}^{c}-z^{c}\right) \beta\left(z^{c}\right)+\varepsilon_{i}
$$

where $\beta\left(z^{c}\right)$ represents the partial derivative of $m(z)$ with respect to $z^{c}$. The estimator of $\delta(z) \equiv\left[m(z), \beta\left(z^{c}\right)\right]^{\prime}$ can be expressed as:

$$
\hat{\delta}(z)=\left[Z^{\prime} K(z) Z\right]^{-1} Z^{\prime} K(z) y
$$

being $Z$ a $n \times\left(q_{c}+1\right)$ matrix with $i$ rows $\left(1,\left(z_{i}^{c}-z^{c}\right)\right)$ and $K(z)$ the $n$ diagonal matrix of product kernel weighting functions. We select a Gaussian kernel for continuous variables; for ordered categorical variables the Wang and Van Ryzin (1981) kernel is chosen. For additional details see Li and Racine (2007) and Henderson and Parmeter (2015).

In non-parametric methodologies the most important point is the selection of appropriate bandwidths, responsible for the degree of smoothing. Among the set of automated bandwidth selection procedures, we select least-squares cross-validation (LSCV), employed in recent studies in the economic growth field (see, for instance, Henderson et al., 2012b, 2013). When using the LLLS estimator, the bandwidths both establish the degree of smoothing and also provide information on the linearity of the independent variables. When a bandwidth of a continuous regressor hits its upper bound means that the regressor behaves in a linear fashion. The upper bounds are set as two standard deviations for continuous variables whereas for ordered discrete variables the upper bound is the unity (see Hall et al., 2007).

As we mentioned in the introduction, non-parametric regression provides observation-specific estimates. In our context, this allows for the construction a posteriori of different groups of countries and/or time periods in order to evaluate whether the effect of our variable of interest is similar in countries sharing similar characteristics and comparable over time. The adequacy of estimating non-parametric regressions is assessed by computing Hsiao et al. (2007) tests. These compare the parametric and non-parametric models and establish which one is preferable. The parametric specification better fits the data if the null hypothesis $(H 0: \operatorname{Pr}[E(x \mid z)=f(z, \beta)]=1)$ cannot be rejected in front of 
the alternative $(H 1: \operatorname{Pr}[E(x \mid z)=f(z, \beta)]<1)$.

\subsection{Endogenous regressors}

Estimations will be biased if endogeneity affects the regressions. In our particular context, it might be argued that NFA is not exogenous to the growth process. We consider this scenario and implement a non-parametric instrumental variables (IV) approach. In doing so, and following recent contributions in the field such as Henderson et al. (2013) we apply the proposal by Su and Ullah (2008), similar in nature to the two-stage least-squares estimation procedure for the parametric scenario. Reconsidering Equation (2), let us assume that there is a single endogenous regressor $w$ :

$$
Y_{i}=m\left(Z_{i}, w_{i}\right)+\varepsilon_{i}, \quad i=1,2, \ldots n
$$

with

$$
w_{i}=n\left(P_{i}\right)+\phi_{i}, \quad i=1,2, \ldots n
$$

where $P_{i}$ in Equation (6) stands for a vector of instruments, $n($.$) represents a$ data-driven function and $\varepsilon_{i}$ and $\phi_{i}$ are the disturbances.

The procedure is implemented in two stages. The first one consists of estimating a regression of the potentially endogenous variable on a set of instruments. In the second stage, the residuals from the first stage are included as an additional regressor, considering also the rest of exogenous variables and the potentially endogenous variable, but excluding the instruments.

The main difficulty in the implementation of the IV regression, however, is the selection of appropriate instruments. In our particular context, it seems especially challenging to find a variable that, on the one hand, is able to explain the external net position of an economy, and, on the other, is exogenous to growth. In that scenario, we follow some proposals in the literature as Temple (1999), arguing that in these cases the lagged values of the endogenous variable can be used as instruments.

\section{Econometric specifications and data}

This section describes the empirical models and the data. Our approach is based on the specification of a Barro-type growth equation that includes not only Solow variables, but also investment and human capital. In this context, we focus on the net external position, where the agents have access to foreign capital and control for financial development, quality of institutions and external openness. In contrast to a strand of the literature that estimates a separate equation for growth and for the determinants of capital inflows (see Mallick and Moore, 2008) or concentrate on the foreign capital model as Alfaro et al. (2008) and Hannan (2017), we estimate an augmented growth equation and focus on the NFA-growth nexus. The reason for this specification is that other variables in the model 
are able to capture the productivity effects on growth associated with capital flows such as foreign direct investment. Other channels related to asymmetric information or risk sharing may be at work and explain the interaction between financial institutions and external imbalances.

In the four model especifications that we estimate the dependent variable is the average growth of real GDP per capita. Model 1 is a simple model which only considers the net external position (NFA) as explanatory variable. Model 2 is a neoclassical Barro-type growth equation (see Barro, 1991), considering as baseline the Solow (1957) model. It includes initial GDP per capita (in logs), population growth, ${ }^{13}$ investment (share of GDP) and a human capital index (in logs). ${ }^{14}$ In this well-known growth regression framework we include the external net position as an additional regressor. ${ }^{15}$ Model 3 incorporates both regional and temporal fixed effects to Model 2. Similarly to Henderson et al. (2013), which evaluates the role of financial development on growth, we make use of the World Bank geographical country classification to generate regional fixed effects, whereas the temporal effects refer to different sub-periods whose information is detailed in the next paragraph. ${ }^{16}$ Finally, Model 4 includes three additional regressors as control variables, namely financial development, trade openness and institutional quality. To measure financial development, following Henderson et al. (2013), we select the ratio of deposit bank assets over deposits money and central bank assets. Trade openness is measured as the ratio of imports plus exports over GDP. Finally, among the wide variety of institutional quality indicators we choose a composite indicator, including corruption, law and order and bureaucratic quality from the World Bank.

The are several reasons that explain the choice of NFA as the variable measuring the external position (and vulnerability) of a country. First, the meticulous database provided by Lane and Milesi-Ferretti allows us to make broad comparisons among countries over a long time span. Second, it includes both external private and public positions. This is important, because boundaries between public and private debt can become blurred in a

\footnotetext{
13 Following Mankiw et al. (1992) and posterior contributions, we add a constant equal to 0.05, which captures depreciation and technological change.

14 As it is common in the literature (see, for instance Badunenko and Romero-Ávila, 2013) the index is constructed using a function based on the average years of education (Barro and Lee, 2013) as well as on the returns to education (Psacharopoulos, 1994). The index is nowadays directly provided by international datasets such as the Penn World Table.

15 The selection of the baseline model is not an easy task. As put forth by Durlauf (2002), the typical crosscountry growth regressions fail to capture all the potential growth determinants. As Durlauf and Quah (1999) and Brock and Durlauf (2001) argue, the fact that one particular theory could predict economic growth does not discredit other alternative theories as growth drivers, which represents the major difficulty for model selection. In practice, however, the ability of the Solow framework and Barro-type growth equations to predict growth in different geographical contexts has meant it is widely used as a starting point when evaluating other theories in growth empirics (see, for instance Durlauf et al., 2008; Henderson et al., 2012b, 2013).

16 However, a model with country fixed effects is not estimated. For the time being, as argued by Henderson and Parmeter (2015), the implementation of the fixed effects estimator presents some difficulties and the literature is still incipient. In our context, an alternative to the fixed effects estimation might be the inclusion of individual dummies but this would dramatically increase the number of regressors (there are 106 countries in the sample). Therefore, following recent contributions in similar contexts (see Henderson et al., 2012b, 2013), we include regional dummies, which would seem to be a balanced strategy.
} 
crisis and excluding external private positions is one the forms of hidden debt and can be even a source of financial instability (see Reinhart and Rogoff, 2014). Third, this measure considers foreign currency-denominated positions, and therefore takes into account the related original sin problems as well as prospective valuation effects. ${ }^{17}$ Fourth, we consider net positions, which seems to offer a better measure of external indebtedness than gross ones (Calderón et al., 2000). However, our choice of the NFA position is not absent from some criticisms. As it has been recently claimed by Dias et al. (2014) using face (undiscounted) value of assets can be misleading because countries can borrow at different maturities and contractual forms (different distributions between principal and interest service). ${ }^{18}$ Another interesting alternative is to study the separate effects of the two components of NFA: assets and liabilities, as well as the breakdown of the types of capital. Examples in the empirical literature are Mallick and Moore (2008), Alfaro et al. (2008) or, more recently, Hannan (2017). ${ }^{19}$ Related to the former point, some authors claim that financial crises affect not only net but gross international capital flows to and from the crisis country, having important consequences on output (Broner et al., 2013; Janus and RieraCrichton, 2015). Finally, concerning the use of the Net International Investment Position $(N I I P)$ for this analysis, the main problem is data availability, as both the span and the number of reporting countries is very limited (see Lane and Milesi-Ferretti, 2007).

Data for the Solow variables and trade openness have been obtained from the PWT 8.1. The information on financial development is available at the Financial Structure Datase (see Beck et al., 2000) (version 2013), whereas information on institutional quality is taken from the Quality of Government Dataset (QoG) 2015. Following the standard practice in the growth literature, we average data for different 5 -year subperiods. ${ }^{20}$ The final sample comprises 550 observations for 106 countries. The list of countries is included in Appendix A.

Table 1 provides some descriptive statistics. Additional information is contained in Figure 1, which displays a world map with the NFA position of the countries in the sample in 2007, the year before the economic crisis started. The map shows that there were only a reduced group of creditor countries at that time, and the rest of the world was a net debtor. The majority of the creditor countries are oil producers (notably Norway, Saudi Arabia and Iran). Others, such as Japan and Germany, are competitive exporters with ageing

\footnotetext{
17 Valuation effects have been very large recently and have acted through the financial channel of external imbalances, as found by Gourinchas and Rey (2007). In contrast to the traditional trade channel, we can assess the nature and dimension of external imbalances by looking at the NFA position of countries. Negative values of the NFA position reflect the cumulated effect of persistent current account deficits. However, a country running persistent current account deficits might be at the same time improving its NFA position if capital gains on its foreign assets exceed those on its foreign liabilities (Lane and Milesi-Ferretti, 2007). With valuation effects, the changes in the NFA position do not coincide with the current account. This may explain some of the imbalances but it is hard to incorporate in the theoretical models.

18 Dias et al. (2014) and Easterly (2002) provide alternative datasets with net present value (NPV) of debt data.

19 This goes beyond the objectives of this paper and it is an interesting research alternative to be addressed in the future thanks to the recent new database provided by Lane and Milesi-Ferretti (2017).

20 Although this strategy implies a significant reduction in the available information, it is useful to reduce the volatility of the dependent variable and to better capture economic cycles.
} 
population. In the case of China, the country has not only surplus in the trade balance, but also an underdeveloped financial system, so that the gains from growth and trade are invested abroad. The rest of the world is a debtor, but only a minority exceed the $100 \%$ threshold.

Figure 2 shows both the evolution and the distribution of NFA and the basic relationship with growth. In particular, panel a) provides the temporal trend for relevant country groups. OECD and EU-15 countries display a very stable evolution during the whole period, close to equilibrium or to a relatively small debtor position. Internally the situation is different, as some of their members have had large imbalances in both directions. Other areas show more volatility although, in general, the net position tends to persist (either creditor or debtor). MENA countries are systematically net creditors, beginning in the 1980s, after the two oil price shocks and the discovery of natural gas and oil reserves in North Africa. In contrast, both Latin American and the Caribbean have a debtor position. Sub-Saharian countries have also been net debtors during a large part of the sample, but their position has reversed at the end of the last decade.

From the violin plots by sub-periods provided in panel b) we might conclude that the distribution of the NFA positions has been relatively stable over the entire period, although they show lower dispersion in the last sub-periods in comparison to the first ones. Finally, panel c) displays the simple relationship between NFA and growth, which is slightly positive. However, it is also observable that beyond the general positive result there are many subtleties that deserve specific attention, which will be studied in detail in the next section.

\section{Results}

In this section we discuss the results of applying the methods presented in Section 3 to Models 1-4. Before applying these methods, however, standard OLS regressions were run to compare linear and non-linear models. Results for the parametric estimations are reported in Table 2. In all models the NFA variable is positive and significant and the estimated parameter does not suffer great variation when control variables are added. After these preliminary regressions, we have estimated the models non-parametrically. Firstly, we computed the bandwidths via least-squares cross-validation to detect nonlinearities. Secondly, we calculated the estimates for the regressors via LLLS, focusing the analysis on the NFA variable and considering potential heterogeneity and its effects across particular groups of countries and temporal periods.

\subsection{Bandwidths}

The upper bounds for the regressors as well as the bandwidths for the different estimators, variables and models are provided in Table 3. In bold are those bandwidths larger than the corresponding upper bound. In general, the majority of the variables enter the models nonlinearly, with the exception of financial development and the initial GDP in Model 4 and the variable of interest (NFA), which enters linearly in Models 2 and 4. 
Table 3 also reports the results for the Hsiao et al. (2007) tests, described in Section 3. They evaluate the appropriateness of the non-parametric estimations against the parametric alternative. In all cases, the null hypothesis that the parametric specification form is correct is clearly rejected. The results suggest that the non-parametric alternative performs better than the parametric linear specification in capturing the causal relationship between GDP per capita growth and the regressors included. Thus, the adoption of a flexible modelling framework seems to be a more appealing approach.

\subsection{Non-parametric estimates for the entire sample}

We now focus on the estimated coefficients. As noted throughout the paper, nonparametric regression techniques allow us to compute individual estimates for each country and temporal period. Table 4 reports LLLS quartile estimates for each regressor and model. These coefficients represent the impact of a given regressor on economic growth assuming that the rest of the variables remain constant at their median values. Wild bootstrap standard errors are provided in parenthesis (see, for computation details, Henderson and Parmeter, 2015).

From the results presented in Table 4 we might conclude that the estimated NFA coefficient is significant in all four models and its size remains virtually unaltered when the different controls are included. However, note that the variability across quartiles is sizable; for instance, considering Model 4 the impact of NFA on growth can be four times larger in some countries (third quartile) than in others (first quartile). ${ }^{21}$ Compared with the parametric estimations, the coefficient size in the non-parametric models is almost double for the third quartile in comparison with the mean estimate provided by OLS and slightly lower for the first quartile. This indicates that the parametric models are underestimating the impact of NFA on growth in some countries and overestimating the effects in others due to model misspecification. For the rest of control variables we also detect some variability in both the size and the significance of the coefficients, although the results are still highly consistent with theory.

These quartile estimates are a useful first approach to analyze the effects of the different variables on growth. Nonetheless, for a complete view of the results the computation of kernel densities for the whole vector of estimated effects is a better choice. Figure 3 displays the density for NFA in all four models. In general, whereas the inclusion of the Solow controls (Model 2) provides similar results to those for Model 1 (simple model), the inclusion of geographical and temporal dummies in Model 3 increases the variability of the estimated parameter (the distribution is less pointed and shows longer tails). With the inclusion of additional controls in Model 4, the estimated density again becomes tighter and similar to Models 1 and 2 . The median estimate, however, is fairly similar in all four models, thus indicating that the coefficient is stable and the estimation does not suffer notable changes when additional variables are included in the model.

The NFA's effect on growth is mainly positive and approximately normal. Most of the effects are ranged in the interval (0-0.04), although higher and lower effects (some of

${ }^{21}$ We will try to identify the countries in each group later in the analysis. 
them negative) are also observed. From Figure 3 and Table 4 we do not perceive important differences in the size of the NFA estimates across models. As a result, from now on we exclusively focus on Model 4, the most comprehensive one that includes all the controls. The kernel density displays the entire distribution of estimates but it does not allow for any real exploration of their significance. Alternatively, $45^{\circ}$ plots such as those proposed by Henderson et al. (2012a) can easily deal with this shortcoming. They consist of plotting the estimates against themselves with their corresponding $95 \%$ bootstrap confidence bands. Those intervals containing the value zero indicate that the associated estimate is not significant. Figure $3 \mathrm{~b}$ ) shows that most of the NFA estimates (Model 4 ) in both the positive and the negative quadrant are significant.

Summarizing, the majority of the NFA gradients have a positive sign. Note however that, according to the theory, both negative and positive signs are possible. Moreover, a negative sign of the NFA parameter in the case of a debtor country (i.e. with a negative NFA position) would have a positive impact on growth.

In order to test whether the results hold when we consider NFA as endogenous, we have applied the Su and Ullah (2008) IV estimation introduced in Section 3. As commented on in that section, given the difficulty to find valid instruments we use the lagged value of NFA. Table 5 provides the results. Comparing the estimates to those from the original Model 4, no remarkable differences are observed. The first quartile is nonsignificant, while the median estimate and the third quartile are almost coincident. For the rest of the variables in the model results are virtually analogous, which provides some evidence on the robustness of the estimations.

\subsection{Non-parametric estimates for particular sample splits}

Considering the most comprehensive Model 4, in this section we explore whether the effects of NFA on growth differ for particular groups of countries and temporal periods. These results are provided in Table $6 .^{22}$ We have classified the results by country groups according to either economic or geographical links. The areas we analyze are the OECD, the EU-15, MENA countries, Sub-Saharian African countries, South-Asian countries and LatinAmerican and Caribbean countries. In general both the size and the significance of the estimated coefficient vary across groups and temporal periods, showing that it is important to focus on particular groups rather than generalize.

For instance, note that for the OECD group the coefficient was not significant during the 1980s and the 1990s but becomes significant in 2003-2007 and practically doubles during the crisis. A similar result is found for the EU-15. ${ }^{23}$ External imbalances accumulated since the end of the 1990s and the beginning of last decade have been significantly offset after the crisis. However, in the international context, foreign capital has not always been

\footnotetext{
22 Note that the estimates for particular sample splits are not the result of partial regressions for these groups. Given that the non-parametric regression provides individual estimates for each observation, the models are run in all cases for the entire sample and the groups (both in terms of countries and temporal periods) are made a posteriori.

${ }^{23}$ This result is expected, since the EU-15 countries are also included in the OECD group.
} 
invested in highly productive sectors. In some cases current account imbalances were due to consumption expenditure and real estate investment, notably in OECD countries, whereas the funds had their origin in emerging countries. This may be the reason, in some cases, for the low impact of NFA positions on growth and the positive signs: rapidly growing countries may have been accumulating positive positions and transferring excess assets to developed countries with more modest rates of growth but with deep financial markets. This explanation, valid for times of bonanza, can be complemented by an excess of demand of safe assets under deleveraging periods as during and after the recent financial crisis.

The previous discussion may also apply to the situation of South-Asian and MENA countries, which were net creditors during the expansion years and for which we found a positive relation between the NFA position and GDP growth, whereas for both the OECD countries and the EU-15 (presenting a small debtor position) no significant link is found. Richer countries with more developed financial systems may not benefit from the financial depth effect, as argued by Arcand et al. (2015). Possibly the Southern Asian countries and the MENA group were growing but their savings did not remain in the domestic economy nor received foreign capital inflows (probably as a result of the Asian Financial crisis); this evidence can be considered in line with the arguments presented in Broner and Ventura (2016). In contrast, for the group of SubSaharian countries, being net debtors over virtually the entire period may have been dampening their economic growth.

Furthermore, in the lower rows we show a different grouping criterion, as we distinguish between debtor and creditor countries. As the majority of the creditor countries are the above-mentioned South-Asian and MENA countries, the same discussion applies in this case. For the debtor countries the relationship is significant for the whole period, although the parameter seems larger and more significant since the end of 1990s, a period of financial globalization for most of them. However, as we will test later, no significant difference has been found between these two groups. This means that being a debtor reduces per capita GDP growth to a similar extent as it would increase growth if the country was a creditor. The comparison between countries growing above and below the mean yields analogous results, which suggest that the impact of NFA on growth is not driven by growth intensity. This suggests that our regressions are not affected by reverse causality.

Based on the theoretical model proposed by Broner and Ventura (2016), we are particularly interested in studying differences in the NFA impact on growth for countries differing in terms of GDP per capita, financial development, trade openness and institutional quality. These factors have been found to be relevant to explain the attractiveness of a country to foreign capital by Alfaro et al. (2008) and are cited as structural or long-run determinants of capital flows by Hannan (2017). As in the previous comparisons we have distinguished between countries with these fundamentals above and below the sample mean. For all cases we find statistically significant differences. In particular, for those countries with GDP per capita levels below the mean we find positive and significant coefficients for all periods with the exception of the crisis years, whereas for the relatively rich economies (above mean GDP per capita) the coefficient is only positive from the late 1990s onwards, which constitutes additional evidence on the too much finance argument by Arcand et al. (2015). An analogous pattern is observed when considering the degree of financial development. The result is somehow expected, since 
countries with relatively high levels of financial development are also those with GDP per capita levels above the mean. The degree of trade openness seems to be related to the NFA effect on growth. While for the countries with relatively low levels of openness the coefficient is significant in virtually all the periods, for more open economies a significant link is observed only for the two latter periods. Finally, distinguishing by institutional quality, countries with healthy institutional systems (above the mean) show only significant coefficients for the latest periods whereas for those below the mean level significant coefficients are found for most of the periods.

The different quadrants in Figure 4 display the associated kernel densities using data for the whole period, allowing for a more descriptive view of the full vector of estimates in the different sample splits. The densities are superimposed in order to ease the analysis of differences. Similarly to the median estimates in Table 6 we obtain differences in some cases whereas in others the computed densities are virtually identical, thus showing no differences between the two compared groups not only in the median, but in the entire distribution. In general, the greatest differences are found for the different geographical comparisons (first quadrant) and the time period comparison for the full sample (last quadrant), although other comparisons with notable differences are those corresponding to GDP per capita levels, institutional quality and external openness. As already discussed above, no differences are observed between countries with high and low growth rates and between debtors and creditors.

For all cases, the hypothesis of equal density distributions is formally tested with the Li (1996) test, which assesses the closeness of two given distributions $h(y)$ and $g(y)$. Under the null hypothesis $(H 0: h(y)=g(y))$, the two distributions are equal. Under the alternative ( $H 1: h(y) \neq g(y))$, they differ statistically. The results for these tests for all the possible pairs are presented in Table 7. The first part of Table 7 is devoted to the geographical country-groups. The majority of the comparisons give the same result: the null hypothesis of equality is rejected. The only exceptions are the case of the OECD versus the EU-15 and the comparisons among the MENA, Sub-Saharian and South-Asian countries. Two of them (MENA and South-Asian) are net creditors. These tests confirm the previous discussion concerning the similarities found among the country-groups estimations for the different data-periods in Table 6. The second part of Table 7 compares all the possible timeperiod pairs in the sample. In this case the null hypothesis is rejected in all cases but for the periods (1988-1992) vs. (2008-2011). In addition, for the case of (1988-1992) vs. (19931997 ) the null hypothesis is rejected at $10 \%$. Thus, this would mean that from the beginning of the 1990s to the end of the sample the behavior of the estimated model is more similar than in the first part of the sample. This result can be clearly observed in the lower-right graph in Figure 4, which shows that the distributions are more biased towards the right and narrower in the second part of the sample.

Due to the relevance of the above-mentioned factors and in order to further exploit all the information contained in our non-parametric estimates, we consider four countrygroups and represent the estimates of the effect of NFA on growth for each of them. The countries are classified into debtors below $50 \%$ of GDP, debtors between $50 \%$ and $100 \%$, debtors over $100 \%$ and, finally, creditor countries. In addition, we consider for 
each group whether financial development, openness and institutional quality is above or below the mean. The median estimates for NFA in Model 4 are presented in Table 8. Following the predictions of Broner and Ventura (2016), it is particularly relevant to analyze the size of the coefficient for creditor countries when the level of financial development is below the mean. This estimate is found to be the largest for all the groups considered (0.016), positive and significant at $1 \%$. The interpretation of this result supports the "capital flight" effect, as for underdeveloped financial systems a positive NFA position means that capital is leaving the country and this has a positive effect on per capita growth. ${ }^{24}$ In contrast, this coefficient is non-significant when financial development is above the mean, confirming the previous results obtained for OECD and EU countries.

A similar interpretation can be given to the role of institutional quality for creditor countries: the parameter is not significant when the institutional quality is above the mean, whereas it is positive and significant when the quality is below the mean. Poor institutional quality may also provoke capital flight and a creditor position in those countries. Alfaro et al. (2008) found similar results in the context of the "Lucas Paradox" literature. The role of openness, however, is oposite: in more open countries with a creditor position an increase in this position has a positive and significant effect on growth, possibly boosting the internationalization of the economy both in terms of trade and investment. The coefficient is, in this case, non-significant for more closed economies. Note that these results would imply that improvements in the net creditor position for countries with strong institutions and developed financial systems would not have any effect on per capita GDP growth. This evidence strongly supports the findings of Arcand et al. (2015) already mentioned above. Moreover, the heterogeneity found between more and less open countries may also point towards the results of Galor and Mountford (2008) and their consequences in terms of development and inequality.

Concerning debtor countries, the role of the control variables also differs depending on the degree of net indebtedness. Even if in these countries the initial NFA position is negative, an increase in the variable implies an improvement in this position. In contrast to the neoclassical theory, all the coefficients are positive (although some of them are not significant). This means that reducing their negative position is good for GDP per capita growth. With regard to more financially developed countries, changes in their position do not have any effect on growth when the NFA percentage over GDP is below $50 \%$. For more indebted countries, reducing their degree of indebtedness has positive effects on growth. The same holds for countries with less developed financial markets: in all cases, including levels below $50 \%$, the improvement in their position is positively related to GDP per capita growth. As for the role of openness, more open countries may suffer strongly the limits posed by external indebtedness: the results agree with this hypothesis as the gradient is 0.008 for debtors below $50 \%, 0.012$ between $50 \%$ and $100 \%$ and reaches 0.015 for those with a negative position over $100 \%$ of GDP. The effect is also significant and of a similar magnitude for less open countries.

Finally, we have presented the results for debtor countries according to their

\footnotetext{
${ }^{24}$ This does not necessarily imply a "flight to safety" but just an outflow searching for better investment opportunities in a more financially developed country.
} 
relative institutional quality. Reducing indebtedness has positive effects for all the possible country groups, although the magnitude is larger for those countries with weaker institutions. This result also agrees with what we found for the creditor countries. The only exceptions are net external debtors over $100 \%$ of GDP with stronger institutions. As for this group an improvement in their position does not have any effect on growth.

\section{Concluding remarks}

In this paper we have applied non-parametric kernel regressions to the analysis of the effect of the NFA position on growth for 106 countries during the period 1983-2011. World external imbalances have increased and accumulated in the last decades and the relevant question from the economic policy point of view is whether these imbalances may hinder further growth. Therefore, as growth is a long-run phenomenon, NFA is a better measure of external imbalances than the current account, as the former is a stock (the difference between accumulated assets and liabilities of a country) and the latter is a flow variable. The chosen econometric approach has allowed us to exploit parameter heterogeneity across countries and over time. We have found that the net foreign position of a country has a positive impact on growth for the majority of the countries and periods. We explicitly compare and test for parametric versus non-parametric specifications, concluding in favor of flexible non-parametric models. Moreover, results robust to endogeneity are also provided in the non-parametric framework.

The positive sign of the coefficients obtained in the majority of the cases should be interpreted with caution, as the value of the NFA is positive for net creditor countries and negative for net debtors. Therefore, the results show that creditor countries tend to perform better in terms of growth than debtors. Although, both signs, positive and negative, can be sustained according to competing theoretical approaches, our results, in principle, are not supportive of the intertemporal agent-based models. On the contrary, our findings are in line with the Lucas Paradox commonly found in the empirical literature. They give support to a recent class of models explaining the macroeconomic consequences of globalization where frictions are present, especially in financial markets, showing that the negative relationship would be a particular case under some restrictive constraints while the general outcome should be a positive sign. More specifically, our results show that the sign, the size and significance of the coefficients may vary significantly depending on the temporal span considered and the idiosyncratic characteristics of the countries analyzed: initial GDP per capita, trade openness, institutional quality, and especially, the level of financial development.

We have found that the sources of heterogeneity in the role of the NFA position on growth has to do, first, with the level of indebtedness (positive for creditors and negative for debtors) and, second, with the relative development of the institutions. Concerning the level of indebtedness, reducing their debtor position increases growth for the most indebted countries, whereas net creditors do not grow more when their positive position improves. With regard to the degree of development of the institutions, the conclusions are somehow of a similar nature: weak institutions are associated with larger and significant 
effects, whereas for the countries with strong institutions the effect is negligible.

These results are aligned with the new models on globalization, such as the one proposed by Broner and Ventura (2016), where the individual characteristics of the economies and the expectations play a crucial role on the effects on growth. In our case, creditor countries with strong institutions and very open to trade are not affected in their growth rate by improvements in their NFA position. Conversely, growth would be constrained for those countries whose level of development is below average, which have weaker institutions and are relatively closed to international trade so that they are unable to improve their external position.

These findings can be useful for the design of future policies seeking economic and financial stability. We have found that the quality of institutions and governance affect the financial fragility associated with capital inflows. However, our empirical findings show that these normative conclusions have clear limits and two lessons can be derived. First, one size does not fit all. Each country has its own particularities that might condition the role of the external position on growth, and therefore general prescriptions should be avoided. Second, the same policy might be appropriate in one country for a given time period but not for another. Accordingly, when it comes to making decisions concerning the external position, a careful assessment of the country-specific conditions at that particular moment is crucial when adopting the most appropriate policy decision.

\section{References}

Aguiar, M. and Amador, M. (2014). Sovereign Debt. In Handbook of International Macroeconomics, volume 4, chapter 11, pages $1-50$.

Aiyagari, R. (1994). Uninsured idiosyncratic risk and aggregate savings. Quarterly Journal of Economics, 109:659- 684.

Alfaro, L., Kalemli-Ozcan, S., and Volosovych, V. (2008). Why doesn't capital flow from rich to poor countries? Review of Economics and Statistics, 90(2):347-368.

Alfaro, L., Kalemli-Ozcan, S., and Volosovych, V. (2014). Sovereigns, Upstream Capital Flows, and Global Imbalances. Journal of the European Economic Association, 12(5):1240-1284.

Antràs, P. and Caballero, R. J. (2009). Trade and Capital Flows: A Financial Frictions Perspective. Journal of Political Economy, 117(4):701-744.

Arcand, J. L., Berkes, E., and Panizza, U. (2015). Too much finance? Journal of Economic Growth, 20(2):105148.

Ayhan Kose, M., Prasad, E. S., and Terrones, M. E. (2009). Does openness to international financial flows raise productivity growth? Journal of International Money and Finance, 28(4):554-580.

Badunenko, O. and Romero-Ávila, D. (2013). Financial development and the sources of growth and 
convergence. International Economic Review, 54(2):629-663.

Barro, R. J. (1991). Economic growth in a cross section of countries. Quarterly Journal of Economics, 106(2):407-443.

Barro, R. J. and Lee, J. W. (2013). A new data set of educational attainment in the World, 1950-2010. Journal of Development Economics, 104:184-198.

Beck, T., Degryse, H., and Kneer, C. (2014). Is more finance better? Disentangling intermediation and size effects of financial systems. Journal of Financial Stability, 10(1):50-64.

Beck, T., Demirgüç-Kunt, A., and Levine, R. (2000). A new database on the structure and development of the financial sector. The World Bank Economic Review, 14(3):597-605.

Blanchard, B. O., Ostry, J. D., Ghosh, A. R., and Chamon, M. (2016). Capital Flows: Expansionary or Contractionary? American Economic Review: Papers \& Proceedings, 106(5):565-569.

Brock, W. A. and Durlauf, S. N. (2001). What have we learned from a decade of empirical research on growth? Growth empirics and reality. World Bank Economic Review, 15(2):229-272.

Broner, F., Didier, T., Erce, A., and Schmukler, S. L. (2013). Gross capital flows: Dynamics and crises. Journal of Monetary Economics, 60(1):113-133.

Broner, F. and Ventura, J. (2016). Rethinking the effects of financial globalization. The Quarterly Journal of Economics, 131(3):1497-1542.

Bussière, M. (2013). Sovereign Debt and Fiscal Policy in the Aftermath of the Financial Crisis: Introduction. The Economic Journal, 123(566):F1-F3.

Bussière, M. and Fratzscher, M. (2006). Towards a new early warning system of financial crises. Journal of International Money and Finance, 25(6):953-973.

Caballero, R. J., Farhi, E., and Gourinchas, P.-O. (2008). An Equilibrium Model of Global Imbalances and Low Interest Rates. American Economic Review, 98(1):358-393.

Calderón, C., Loayza, N., and Serven, L. (2000). External Sustainability: A Stock Equilibrium Perspective. World Bank Policy Research Working Paper, 2281.

Catão, L. A. V. and Milesi-Ferretti, G. M. (2014). External liabilities and crises. Journal of International Economics, 94(1):18-32.

Cecchetti, S. G. and Kharroubi, E. (2012). Reassessing the impact of finance on growth. BIS Working Paper, (February):1-21.

Checherita-Westphal, C. and Rother, P. (2012). The impact of high government debt on economic growth and its channels: An empirical investigation for the euro area. European Economic Review, 56(7):13921405. 
Clements, B. J., Bhattacharya, R., and Nguyen, T. Q. (2003). External Debt, Public Investment, and Growth in Low-Income Countries. IMF Working Papers, 249.

Cohen, D. (1997). Growth and External Debt: A new perspective on the African and Latin American tragedies. CEPR Discussion Paper Series, 1753.

Dias, D. a., Richmond, C., and Wright, M. L. (2014). The stock of external sovereign debt: Can we take the data at'face value'? Journal of International Economics, 94(1):1-17.

Durlauf, S. N. (2002). On the empirics of social capital. Economic Journal, 112(483):459-479.

Durlauf, S. N., Kourtellos, A., and Tan, C. M. (2008). Are any growth theories robust? The Economic Journal, 118(527):329-346.

Durlauf, S. N. and Quah, D. T. (1999). The new empirics of economic growth. In Taylor, J. B. and Woodford, M., editors, Handbook of Macroeconomics, volume 1A, chapter 4, pages 235-308. North-Holland, Amsterdam.

Easterly, W. (2002). How did heavily indebted poor countries become heavily indebted? Reviewing two decades of debt relief. World Development, 30(10):1677-1696.

Ferrero, A. (2010). A structural decomposition of the U.S. trade balance: Productivity, demographics and fiscal policy. Journal of Monetary Economics, 57(4):478-490.

Forbes, K., Hjortsoe, I., and Nenova, T. (2017). Current Account Deficits During Heightened Risk: Menacing or Mitigating? The Economic Journal, 127(601):571-623.

Galor, O. and Mountford, A. (2008). Trading Population for Productivity: Theory and Evidence. Review of Economic Studies, 85(4):1143-1179.

Gourinchas, P. and Rey, H. (2007). International Financial Adjustment. Journal of Political Economy, 115(4):665- 703 .

Gourinchas, P. and Rey, H. (2014). External Adjustment, Global Imbalances, Valuation Effects. In Gopinath, G., Helpman, E., and Rogoff, K., editors, Handbook of International Economics, Volume 4, volume 4, chapter 10, pages 585-645. Elsevier B.V.

Gourinchas, P.-O. and Jeanne, O. (2013). Capital Flows to Developing Countries: The Allocation Puzzle. The Review of Economic Studies, 80(4):1484-1515.

Hall, P., Li, Q., and Racine, J. S. (2007). Nonparametric estimation of regression functions in the presence of irrelevant regressors. The Review of Economics and Statistics, 89(4):784-789.

Hannan, S. A. (2017). The Drivers of Capital Flows in Emerging Markets Post Global Financial Crisis. IMF 


\section{Working Paper, 52.}

Henderson, D. J., Kumbhakar, S. C., and Parmeter, C. F. (2012a). A simple method to visualize results in nonlinear regression models. Economics Letters, 117(3):578-581.

Henderson, D. J., Papageorgiou, C., and Parmeter, C. F. (2012b). Growth empirics without parameters. Economic Journal, 122(559):125-154.

Henderson, D. J., Papageorgiou, C., and Parmeter, C. F. (2013). Who benefits from financial development? New methods, new evidence. European Economic Review, 63:47-67.

Henderson, D. J. and Parmeter, C. F. (2015). Applied Nonparametric Econometrics. Cambridge University Press. New York.

Hsiao, C., Li, Q., and Racine, J. S. (2007). A consistent model specification test with mixed categorical and continuous data. Journal of Econometrics, 140(2):802-826.

Imbs, J. and Ranciere, R. (2005). The Overhang Hangover. World Bank Policy Research Working Paper, 3673.

IMF (2014). The Fund's Lending Framework and Sovereign Debt and Preliminary Considerations. Staff Report, (June).

Janus, T. and Riera-Crichton, D. (2015). The output effect of gross foreign investment reversals. Oxford Economic Papers, 67(2):356-379.

Jin, K. (2012). Industrial structure and capital flows. American Economic Review, 102(5):2111-2146.

Lane, P. R. and Milesi-Ferretti, G. M. (2001). The external wealth of nations: Measures of foreign assets and liabilities for industrial and developing countries. Journal of International Economics, 55(2):263-294.

Lane, P. R. and Milesi-Ferretti, G. M. (2007). The external wealth of nations mark II: Revised and extended estimates of foreign assets and liabilities, 1970-2004. Journal of International Economics, 73(2):223-250.

Lane, P. R. and Milesi-Ferretti, G. M. (2017). International Financial Integration in the Aftermath of the Global Financial Crisis. IMF Working Paper, 115.

Levine, R. (2005). Finance and growth: theory, evidence, and mechanisms. In Aghion, P. and Durlauf, S., editors, The Handbook of Economic Growth, volume 1A of Handbooks in Economics, chapter 12. NorthHolland, Amsterdam.

Li, Q. (1996). Nonparametric testing of closeness between two unknown distribution functions. Econometric Reviews, 15:261-274.

Li, Q. and Racine, J. S. (2007). Nonparametric Econometrics: Theory and Practice. Princeton University Press, Princeton and Oxford.

Lucas, R. E. (1990). Why Doesn't Capital Flow from Rich to Poor Countries? The American Economic Review, 
$80(2): 92$.

Mallick, S. and Moore, T. (2008). Foreign capital in a growth model. Review of Development Economics, $12(1): 143-159$.

Mankiw, N., Romer, D., and Weil, D. (1992). A contribution to the empirics of economic growth. Quarterly Journal of Economics, 107(2):407-437.

Mendoza, E. G., Quadrini, V., and Ríos-Rull, J.-V. (2009). Financial Integration, Financial Development, and Global Imbalances. Journal of Political Economy, 117(3):371-416.

Obstfeld, M. (2009). International Finance and Growth in Developing Countries: What Have We Learned? IMF Staff Papers, 56(1):63-111.

Obstfeld, M. and Rogoff, K. (1996). Foundations of International Macroeconomics. Massachusetts Institute of Technology, Cambridge, MA.

Pattillo, C., Poirson, H., and Ricci, L. A. (2011). External Debt and Growth. Review of Economics and Institutions, 2(3):1-30.

Peiró-Palomino, J. (2016). Social capital and economic growth in Europe: Nonlinear trends and heterogeneous regional effects. Oxford Bulletin of Economics and Statistics, 78(5):717-751.

Peiró-Palomino, J. (2017). The geography of social capital and innovation in the European Union. Papers in Regional Science, Forthcoming.

Prasad, E. S., Rajan, R. G., and Subramanian, A. (2007). Foreign Capital and Economic Growth. Brookings Papers on Economic Activity, (1):153-230.

Presbitero, A. (2008). The Debt-Growth Nexus in Poor Countries: A Reassessment. Economics: The OpenAccess, Open-Assessment E-Journal, 2(30):1-28.

Psacharopoulos, G. (1994). Returns to investment in education: A global update. World Development, 22(9):1325- 1343.

Racine, J. S. and Li, Q. (2004). Nonparametric estimation of regression functions with both categorical and continuous data. Journal of Econometrics, 119(1):99-130.

Reinhart, C. M. and Rogoff, K. S. (2014). Financial and Sovereign Debt Crises: Some Lessons Learned and Those Forgotten. In Claessens, S., Kose, M., and Laeven, L., editors, Financial Crisis: Causes, Consequences, and Policy Responses. IMF, Washington, D.C.

Sanso-Navarro, M. and Vera-Cabello, M. (2016). Regional growth, innovation, and latent nonlinear effects. Journal of Regional Science, 56(5):814-847. 
Schclarek, A. (2004). Debt and Economic Growth in Developing and Industrial Countries. Lund University Working Paper, 46(0):1-37.

Smyth, D. J. and Hsing, Y. (1995). In search of an optimal debt ratio for economic growth. Contemporary Economic Policy, XIII:51-60.

Solow, R. M. (1957). Technical change and the aggregate production function. Review of Economics and Statistics, 39(3):312-320.

Su, L. and Ullah, A. (2008). Local polynomial estimation of nonparametric simultaneous equations models. Journal of Econometrics, 144(1):193-218.

Temple, J. (1999). The new growth evidence. Journal of Economic Literature, 37(1):112-156.

Wang, M.-C. and Van Ryzin, J. (1981). A class of smooth estimators for discrete distributions. Biometrika, 68(1):301-309. 
Table 1: Descriptive statistics

\begin{tabular}{|l|l|l|l|l|l|l|l|l|}
\hline Variable & Obs. & Mean & s.d. & Min. & 1 st quartile & Median & 3rd quartile & Max. \\
\hline GDP pc growth & 550 & 0.020 & 0.029 & -0.094 & 0.005 & 0.019 & 0.034 & 0.130 \\
\hline NFA & 550 & -0.369 & 0.657 & -3.280 & -0.646 & -0.365 & -0.126 & 3.443 \\
\hline Initial GDP per capita & 550 & 8.765 & 1.247 & 5.483 & 7.846 & 8.870 & 9.855 & 11.618 \\
\hline Population growth & 550 & 0.016 & 0.014 & -0.026 & 0.005 & 0.015 & 0.025 & 0.137 \\
\hline Investment & 550 & 0.202 & 0.078 & 0.012 & 0.147 & 0.202 & 0.250 & 0.484 \\
\hline Human capital & 550 & 0.366 & 0.117 & 0.045 & 0.292 & 0.394 & 0.458 & 0.558 \\
\hline $\begin{array}{l}\text { Financial } \\
\text { development }\end{array}$ & 550 & 4.393 & 0.306 & 2.673 & 4.327 & 4.506 & 4.584 & 4.605 \\
\hline Openness & 550 & 0.580 & 0.926 & 0.037 & 0.245 & 0.386 & 0.683 & 16.003 \\
\hline Institutional quality & 550 & 0.576 & 0.228 & 0.056 & 0.422 & 0.544 & 0.736 & 1.000 \\
\hline Notes: Initial GDP per capita and human capital are in logarithms. \\
\hline
\end{tabular}


Table 2: Parametric OLS estimations

\begin{tabular}{|c|c|c|c|c|}
\hline & \multicolumn{4}{|c|}{ Dependent variable: GDP pc growth } \\
\hline Variables & Model 1 & Model 2 & Model 3 & Model 4 \\
\hline \multirow[t]{2}{*}{ Intercept } & $0.022 * * *$ & $0.086 * * *$ & $0.098 * * *$ & $0.110 * * *$ \\
\hline & $(0.001)$ & $(0.011)$ & $(0.012)$ & $(0.022)$ \\
\hline \multirow[t]{2}{*}{ NFA } & $0.006 * * *$ & $0.009 * * *$ & $0.007^{* * *}$ & $0.008 * * *$ \\
\hline & $(0.001)$ & $(0.002)$ & $(0.002)$ & $(0.002)$ \\
\hline \multirow[t]{2}{*}{ Initial GDP per capita } & & $-0.011 * * *$ & $-0.010 * * *$ & $-0.013 * * *$ \\
\hline & & $(0.001)$ & $(0.001)$ & $(0.002)$ \\
\hline \multirow[t]{2}{*}{ Population growth } & & $-0.517 * * *$ & $-0.485 * * *$ & $-0.480 * * *$ \\
\hline & & $(0.093)$ & $(0.106)$ & $(0.105)$ \\
\hline \multirow[t]{2}{*}{ Investment } & & $0.934 * * *$ & $0.064 * * *$ & $0.079 * * *$ \\
\hline & & $(0.017)$ & $(0.018)$ & $(0.018)$ \\
\hline \multirow[t]{2}{*}{ Human capital } & & $0.065^{* * *}$ & $0.033^{*}$ & $0.041^{* *}$ \\
\hline & & $(0.017)$ & $(0.018)$ & $(0.018)$ \\
\hline \multirow[t]{2}{*}{$\begin{array}{l}\text { Financial } \\
\text { development }\end{array}$} & & & & 0.001 \\
\hline & & & & $(0.004)$ \\
\hline \multirow[t]{2}{*}{ Openness } & & & & $-0.005 * * *$ \\
\hline & & & & $(0.001)$ \\
\hline \multirow[t]{2}{*}{ Institutional quality } & & & & 0.010 \\
\hline & & & & $(0.008)$ \\
\hline$N$ & 550 & 550 & 550 & 550 \\
\hline$R^{2}($ Adjusted $)$ & 0.020 & 0.195 & 0.298 & 0.318 \\
\hline$F_{S T A T}$ & $12.05 * * *$ & $27.52 * * *$ & $14.74 * * *$ & $13.80 * * *$ \\
\hline Region control & No & No & Yes & Yes \\
\hline Time control & No & No & Yes & Yes \\
\hline
\end{tabular}


Table 3: LLLS, bandwidths and model specification tests (Hsiao, et al. 2007)

\begin{tabular}{|l|l|l|l|l|l|}
\hline \multicolumn{5}{|c|}{ Dependent variable: GDP pc growth } \\
\hline Variables & UB & Model 1 & Model 2 & Model 3 & Model 4 \\
\hline NFA & 1.313 & 0.593 & 5.028 & 0.935 & $\mathbf{1 1 0 . 9 0 3}$ \\
\hline Initial GDP per capita & 2.494 & & 1.092 & 1.259 & $\mathbf{3 3 . 3 0 7}$ \\
\hline Population growth & 0.029 & & 0.011 & 0.005 & 0.014 \\
\hline Investment & 0.157 & & 0.052 & 0.036 & 0.059 \\
\hline Human capital & 0.233 & & 0.097 & 0.069 & 0.082 \\
\hline Financial development & 0.613 & & & & 0.902 \\
\hline Openness & 1.851 & & & & 1.235 \\
\hline Institutional quality & 0.456 & & & & 0.252 \\
\hline Region & 1.000 & & & 0.625 & 0.991 \\
\hline Time & 1.000 & & & 0.372 & 0.264 \\
\hline Jn -statistic & & 2.259 & 3.518 & 8.507 & 8.099 \\
\hline & & $(0.000)$ & $(0.000)$ & $(0.000)$ & $(0.000)$ \\
\hline
\end{tabular}

Notes: Least Squares Cross Validation (LSCV) bandwidths. A bandwidth in bold denotes that it hits the upper bound (UB), indicating linearity. The $J n$-statistic is the result of the test for correct specification form (Hsiao, et al. 2007). Bootstrap (399 repetitions) p-values are in parenthesis. 
Table 4: LLLS, quartile estimates

\begin{tabular}{|c|c|c|c|c|c|c|c|c|c|c|c|c|}
\hline \multirow[b]{3}{*}{ Variable } & \multicolumn{12}{|c|}{ Dependent variable: GDP pc growth } \\
\hline & \multicolumn{3}{|c|}{ Model 1} & \multicolumn{3}{|c|}{ Model 2} & \multicolumn{3}{|c|}{ Model 3} & \multicolumn{3}{|c|}{ Model 4} \\
\hline & Q1 & Q2 & Q3 & Q1 & Q2 & Q3 & Q1 & Q2 & Q3 & Q1 & Q2 & Q3 \\
\hline \multirow[t]{2}{*}{ NFA } & $0.008 * * *$ & $0.012 * * *$ & $0.015^{* * *}$ & $0.006 * * *$ & $0.010 * * *$ & $0.014 * * *$ & -0.001 & 0.008 & $0.019 * * *$ & 0.004 & $0.011 * * *$ & $0.016 * * *$ \\
\hline & $(0.003)$ & $(0.002)$ & $(0.002)$ & $(0.002)$ & $(0.002)$ & $(0.003)$ & $(0.007)$ & $(0.007)$ & $(0.005)$ & $(0.008)$ & $(0.001)$ & $(0.003)$ \\
\hline \multirow[t]{2}{*}{ Initial GDP per capita } & & & & $-0.207 * * *$ & $-0.018 * * *$ & $-0.011 * * *$ & $-0.026 * * *$ & -0.015 & -0.004 & $-0.024 * * *$ & $-0.017 * * *$ & $-0.009 * * *$ \\
\hline & & & & $(0.003)$ & $(0.004)$ & $(0.003)$ & $(0.003)$ & $(0.012)$ & $(0.008)$ & $(0.003)$ & $(0.003)$ & $(0.002)$ \\
\hline \multirow[t]{2}{*}{ Population growth } & & & & $-1.220 * * *$ & $-0.762 * * *$ & $-0.402 * * *$ & $-1.556 *$ & -0.714 & -0.021 & $-1.270 * * *$ & -0.892 & $-0.497 * * *$ \\
\hline & & & & $(0.333)$ & $(0.206)$ & $(0.206)$ & $(0.857)$ & $(0.597)$ & (0.761) & $(0.255)$ & $(0.555)$ & $(0.251)$ \\
\hline \multirow[t]{2}{*}{ Investment } & & & & $0.063^{* * *}$ & $0.092 * * *$ & $0.127 * * *$ & 0.005 & 0.077 & $0.166^{*}$ & 0.049 & $0.087 * * *$ & $0.128 * * *$ \\
\hline & & & & $(0.024)$ & $(0.024)$ & $(0.039)$ & $(0.188)$ & $(0.066)$ & (0.099) & $(0.049)$ & $(0.021)$ & $(0.043)$ \\
\hline \multirow[t]{2}{*}{ Human capital } & & & & 0.015 & $0.074^{* *}$ & $0.093 * * *$ & -0.021 & 0.065 & $0.126 * * *$ & 0.000 & $0.062 * * *$ & $0.104 * * *$ \\
\hline & & & & $(0.064)$ & $(0.027)$ & $(0.032)$ & $(0.103)$ & $(0.051)$ & $(0.033)$ & $(0.038)$ & $(0.026)$ & $(0.040)$ \\
\hline \multirow[t]{2}{*}{ Financial development } & & & & & & & & & & -0.015 & 0.004 & $0.032^{* * *}$ \\
\hline & & & & & & & & & & $(0.018)$ & $(0.008)$ & $(0.010)$ \\
\hline \multirow[t]{2}{*}{ Openness } & & & & & & & & & & -0.005 & 0.001 & $0.007^{* * *}$ \\
\hline & & & & & & & & & & $(0.003)$ & $(0.003)$ & $(0.007)$ \\
\hline \multirow[t]{2}{*}{ Institutional quality } & & & & & & & & & & -0.006 & 0.009 & $0.029 * * *$ \\
\hline & & & & & & & & & & $(0.013)$ & $(0.011)$ & $(0.013)$ \\
\hline$N$ & & 550 & & & 550 & & & 550 & & & 550 & \\
\hline$R^{2}$ & & 0.055 & & & 0.463 & & & 0.848 & & & 0.784 & \\
\hline Region control & & No & & & No & & & Yes & & & Yes & \\
\hline Time control & & No & & & No & & & Yes & & & Yes & \\
\hline
\end{tabular}


Table 5: IV regression for Model 4, LLLS quartile estimates

\begin{tabular}{|c|c|c|c|}
\hline \multirow[b]{2}{*}{ Variable } & \multicolumn{3}{|c|}{ Dependent variable: GDP pc growth } \\
\hline & Q1 & Q2 & Q3 \\
\hline \multirow[t]{2}{*}{ NFA } & -0.002 & $0.007 * *$ & $0.014 * * *$ \\
\hline & $(0.007)$ & $(0.003)$ & $(0.005)$ \\
\hline \multirow[t]{2}{*}{ Initial GDP per capita } & $-0.025 * * *$ & $-0.013 * * *$ & $-0.005^{* *}$ \\
\hline & $(0.005)$ & $(0.002)$ & $(0.002)$ \\
\hline \multirow[t]{2}{*}{ Population growth } & $-0.990 * * *$ & $-0.629 * * *$ & -0.266 \\
\hline & $(0.115)$ & $(0.115)$ & $(0.209)$ \\
\hline \multirow[t]{2}{*}{ Investment } & $0.058^{*}$ & $0.107^{* *}$ & $0.174 * * *$ \\
\hline & $(0.035)$ & $(0.046)$ & $(0.050)$ \\
\hline \multirow[t]{2}{*}{ Human capital } & 0.006 & $0.077 * * *$ & $0.125 * *$ \\
\hline & $(0.032)$ & $(0.028)$ & $(0.051)$ \\
\hline \multirow[t]{2}{*}{ Financial development } & $-0.016 * * *$ & 0.007 & $0.036 * * *$ \\
\hline & $(0.004)$ & $(0.011)$ & $(0.014)$ \\
\hline \multirow[t]{2}{*}{ Openness } & -0.006 & -0.002 & 0.003 \\
\hline & $(0.004)$ & $(0.026)$ & $(0.004)$ \\
\hline \multirow[t]{2}{*}{ Institutional quality } & -0.019 & 0.005 & $0.027 * *$ \\
\hline & $(0.029)$ & $(0.038)$ & $(0.013)$ \\
\hline$N$ & 444 & & \\
\hline$R^{2}$ & 0.887 & & \\
\hline Region control & Yes & & \\
\hline Time control & Yes & & \\
\hline \multicolumn{4}{|c|}{$\begin{array}{l}\text { Notes: The instrument used is the lagged value of NFA. The first (Q1), median (Q2) and } \\
\text { third (Q3) quartile of the vector of gradients for each continuous variable are reported } \\
\text { Bootstrap standard errors are in parenthesis. Estimations are performed keeping the } \\
\text { rest of variables constant at their median. }{ }^{*}, * * \text { and }{ }^{* * *} \text { denote significance at } 10 \% \\
5 \% \text {, and } 1 \% \text { significance levels, respectively. }\end{array}$} \\
\hline
\end{tabular}


Table 6: LLLS, median estimates for NFA in Model 4 for representative groups of countries and time periods

\begin{tabular}{|c|c|c|c|c|c|c|}
\hline & \multicolumn{6}{|c|}{ Dependent variable: GDP pc growth } \\
\hline & 1983-1987 & $1988-1992$ & 1993-1997 & $1998-2002$ & $2003-2007$ & $2008-2011$ \\
\hline \multirow[t]{2}{*}{ Full sample } & $0.008^{*}$ & $0.010 * * *$ & $0.008^{*}$ & $0.015 * * *$ & $0.014 * * *$ & $0.011 * * *$ \\
\hline & $(0.004)$ & $(0.004)$ & $(0.004)$ & $(0.003)$ & $(0.002)$ & $(0.004)$ \\
\hline \multirow[t]{2}{*}{ OECD } & 0.002 & 0.009 & 0.002 & 0.001 & $0.008 * * *$ & $0.016^{* * *}$ \\
\hline & $(0.006)$ & $(0.007)$ & $(0.007)$ & $(0.002)$ & $(0.002)$ & $(0.002)$ \\
\hline \multirow[t]{2}{*}{ EU-15 } & 0.005 & 0.004 & 0.005 & 0.003 & $0.009 * * *$ & $0.016 * * *$ \\
\hline & $(0.009)$ & $(0.004)$ & $(0.009)$ & $(0.003)$ & $(0.002)$ & $(0.002)$ \\
\hline \multirow[t]{2}{*}{ MENA } & $0.015^{* * *}$ & $0.009 * *$ & $0.009 *$ & $0.016 * * *$ & $0.016 * * *$ & $0.009 * * *$ \\
\hline & $(0.003)$ & $(0.004)$ & $(0.005)$ & $(0.004)$ & $(0.003)$ & $(0.003)$ \\
\hline \multirow[t]{2}{*}{ SubSaharian } & 0.005 & $0.010 * * *$ & $0.007^{*}$ & $0.019 * * *$ & $0.016 * * *$ & 0.002 \\
\hline & $(0.004)$ & $(0.004)$ & $(0.004)$ & $(0.006)$ & $(0.004)$ & $(0.004)$ \\
\hline \multirow[t]{2}{*}{ Southasian } & $0.015^{* *}$ & 0.001 & 0.005 & $0.015^{*}$ & $0.015^{* * *}$ & $0.012 * * *$ \\
\hline & (0.007) & (0.010) & $(0.014)$ & $(0.009)$ & $(0.003)$ & $(0.005)$ \\
\hline \multirow[t]{2}{*}{ Latin-Caribbean } & $0.015^{* * *}$ & $0.015^{* * *}$ & $0.011 * * *$ & $0.019 * * *$ & $0.016 * * *$ & $0.010 * * *$ \\
\hline & $(0.004)$ & $(0.004)$ & $(0.005)$ & $(0.006)$ & $(0.004)$ & $(0.004)$ \\
\hline \multirow[t]{2}{*}{ Debtor countries } & $0.008^{*}$ & $0.010^{* *}$ & $0.008^{*}$ & $0.015^{* * *}$ & $0.015^{* * *}$ & $0.011^{* *}$ \\
\hline & $(0.004)$ & $(0.005)$ & $(0.004)$ & $(0.005)$ & $(0.002)$ & $(0.005)$ \\
\hline \multirow[t]{2}{*}{ Creditor countries } & 0.007 & 0.007 & 0.002 & $0.004^{* *}$ & $0.010 * * *$ & $0.014^{* * *}$ \\
\hline & $(0.005)$ & $(0.011)$ & $(0.004)$ & $(0.002)$ & $(0.002)$ & $(0.003)$ \\
\hline \multirow[t]{2}{*}{ Growth above mean } & 0.004 & $0.008 * * *$ & 0.008 & $0.009 * * *$ & $0.016 * * *$ & $0.010 * * *$ \\
\hline & $(0.005)$ & $(0.003)$ & $(0.006)$ & $(0.003)$ & $(0.004)$ & $(0.003)$ \\
\hline \multirow[t]{2}{*}{ Growth below mean } & 0.012 & $0.011^{* * *}$ & 0.007 & $0.017 * * *$ & 0.008 & $0.015^{* * *}$ \\
\hline & $(0.011)$ & $(0.005)$ & $(0.007)$ & $(0.005)$ & $(0.005)$ & $(0.002)$ \\
\hline \multirow[t]{2}{*}{ GDP pc above mean } & 0.004 & 0.009 & 0.004 & $0.006 * * *$ & $0.011 * * *$ & $0.015^{* * *}$ \\
\hline & $(0.005)$ & $(0.007)$ & $(0.004)$ & $(0.002)$ & $(0.002)$ & $(0.002)$ \\
\hline \multirow[t]{2}{*}{ GDP pc below mean } & $0.011 * * *$ & $0.011 * *$ & $0.009 *$ & $0.018^{* * *}$ & $0.016 * * *$ & $0.015^{* * *}$ \\
\hline & $(0.003)$ & $(0.005)$ & $(0.005)$ & $(0.005)$ & $(0.004)$ & $(0.002)$ \\
\hline \multirow[t]{2}{*}{$\begin{array}{l}\text { Financial development } \\
\text { above mean }\end{array}$} & 0.005 & 0.009 & 0.006 & $0.010^{*}$ & $0.013^{* * *}$ & $0.013^{* * *}$ \\
\hline & $(0.008)$ & $(0.008)$ & $(0.005)$ & $(0.006)$ & $(0.002)$ & $(0.005)$ \\
\hline \multirow{2}{*}{$\begin{array}{l}\text { Financial development } \\
\text { below mean }\end{array}$} & $0.010^{* * *}$ & $0.012 * * *$ & $0.009 * * *$ & $0.019 * * *$ & $0.016^{* * *}$ & 0.002 \\
\hline & $(0.003)$ & $(0.003)$ & $(0.004)$ & $(0.007)$ & $(0.004)$ & $(0.005)$ \\
\hline \multirow[t]{2}{*}{ Openness above mean } & 0.004 & 0.009 & 0.002 & 0.003 & $0.010 * * *$ & $0.016 * * *$ \\
\hline & $(0.005)$ & $(0.008)$ & $(0.005)$ & $(0.002)$ & $(0.002)$ & $(0.002)$ \\
\hline \multirow[t]{2}{*}{ Openness below mean } & $0.008^{* *}$ & $0.011^{* * *}$ & 0.009 & $0.016^{* * *}$ & $0.016^{* * *}$ & $0.009 * *$ \\
\hline & $(0.003)$ & $(0.004)$ & $(0.007)$ & $(0.005)$ & $(0.004)$ & $(0.004)$ \\
\hline \multirow{2}{*}{$\begin{array}{l}\text { Institutional quality } \\
\text { above mean }\end{array}$} & 0.003 & 0.009 & 0.004 & 0.003 & $0.010 * * *$ & $0.016 * * *$ \\
\hline & $(0.005)$ & $(0.007)$ & $(0.004)$ & $(0.003)$ & $(0.002)$ & $(0.002)$ \\
\hline \multirow{2}{*}{$\begin{array}{l}\text { Institutional quality } \\
\text { below mean }\end{array}$} & 0.011 & $0.011^{* * *}$ & 0.010 & $0.019 * * *$ & $0.016^{* * *}$ & $0.009 * *$ \\
\hline & $(0.011)$ & $(0.004)$ & $(0.007)$ & $(0.006)$ & $(0.003)$ & $(0.004)$ \\
\hline
\end{tabular}


Table 7: Non-parametric comparison of the estimated densities for different groups in Model 4

\begin{tabular}{|c|c|}
\hline Compared distributions & t-statistic \\
\hline OECD vs. EU-15 & -1.227 \\
\hline OECD vs. MENA & $3.872 * * *$ \\
\hline OECD vs. SubSaharian & $6.987 * * *$ \\
\hline OECD vs. South-Asian & $1.797^{* *}$ \\
\hline OECD vs. Latin-Caribbean & $23.540 * * *$ \\
\hline EU-15 vs. MENA & $3.039 * * *$ \\
\hline EU-15 vs. SubSaharian & $5.143 * * *$ \\
\hline EU-15 vs. South-Asian & $2.262 * *$ \\
\hline EU-15 vs. Latin-Caribbean & $17.260 * * *$ \\
\hline MENA vs. SubSaharian & 1.080 \\
\hline MENA vs. South-Asian & -0.163 \\
\hline MENA vs. Latin-Caribbean & $1.980 * *$ \\
\hline SubSaharian vs. South-Asian & 1.075 \\
\hline SubSaharian vs. Latin-Caribbean & $10.711 * * *$ \\
\hline South-Asian vs. Latin-Caribbean & $1.874^{* *}$ \\
\hline $1983-1987$ vs. $1988-1992$ & $3.312 * * *$ \\
\hline $1983-1987$ vs. $1993-1997$ & $6.170 * * *$ \\
\hline 1983-1987 vs. $1998-2002$ & $2.778 * * *$ \\
\hline $1983-1987$ vs. 2003-2007 & $13.358 * * *$ \\
\hline $1983-1987$ vs. $2008-2011$ & $4.275^{* * *}$ \\
\hline 1988-1992 vs. $1993-1997$ & $1.632^{*}$ \\
\hline 1988-1992 vs. $1998-2002$ & $10.002^{* * *}$ \\
\hline $1988-1992$ vs. $2003-2007$ & $4.099 * *$ \\
\hline $1988-1992$ vs. $2008-2011$ & 0.118 \\
\hline 1993-1997 vs. 1998-2002 & $20.456 * * *$ \\
\hline 1993-1997 vs. 2003-2007 & $17.361 * * *$ \\
\hline 1993-1997 vs. 2008-2011 & $8.613^{* * *}$ \\
\hline 1998-2002 vs. $2003-2007$ & $12.832 * * *$ \\
\hline $1998-2002$ vs. $2008-2011$ & $6.307 * * *$ \\
\hline 2003-2007 vs. $2008-2011$ & $2.363 * * *$ \\
\hline Above vs. below mean growth rate & 0.709 \\
\hline Debtor countries vs. creditor countries & 0.220 \\
\hline Above vs. below mean GDP pc & $5.322 * * *$ \\
\hline Above vs. below mean financial development & $1.716^{*}$ \\
\hline Above vs. below mean openness & $2.993 * * *$ \\
\hline Above vs. below mean institutional quality & $17.153^{* * *}$ \\
\hline
\end{tabular}


Table 8: LLLS, median estimates for NFA in Model 4 for countries with different debt thresholds and individual characteristics (1983-2011)

\begin{tabular}{|l|l|l|l|l|}
\hline \multicolumn{5}{|l|}{ Dependent variable: GDP pc growth } \\
\hline & Debtors (0\%-50\%) & Debtors (50\%-100\%) & Debtors (>100\%) & Creditors \\
\hline $\begin{array}{l}\text { Financial development } \\
\text { above mean }\end{array}$ & 0.010 & $0.012^{* * *}$ & $0.010^{* * *}$ & 0.009 \\
\hline & $(0.006)$ & $(0.002)$ & $(0.002)$ & $(0.008)$ \\
\hline $\begin{array}{l}\text { Financial development } \\
\text { below mean }\end{array}$ & $0.012^{* *}$ & $0.011^{* * *}$ & $0.010^{* *}$ & $0.016^{* * *}$ \\
\hline & $(0.005)$ & $(0.003)$ & $(0.005)$ & $(0.004)$ \\
\hline Openness above mean & $0.008^{* * *}$ & $0.012^{* * *}$ & $0.015^{* * *}$ & $0.010^{* * *}$ \\
\hline & $(0.002)$ & $(0.003)$ & $(0.003)$ & $(0.002)$ \\
\hline Openness below mean & $0.012^{* * *}$ & $0.011^{* * *}$ & $0.010^{* *}$ & 0.009 \\
\hline $\begin{array}{l}\text { Institutional quality above } \\
\text { mean }\end{array}$ & $(0.005)$ & $(0.005)$ & $(0.005)$ & $(0.007)$ \\
\hline & $0.007^{* * *}$ & $0.011^{* * *}$ & 0.004 & 0.009 \\
\hline $\begin{array}{l}\text { Institutional quality below } \\
\text { mean }\end{array}$ & $(0.002)$ & $(0.003)$ & $(0.003)$ & $(0.008)$ \\
\hline & $(0.003)$ & $0.012^{* * *}$ & $0.011^{* * *}$ & $0.010^{* * *}$ \\
\hline
\end{tabular}

Notes: Median values of the vector of partial effects of NFA in each subgroup. Bootstrap standard errors are in parenthesis. : ${ }^{*}, *$ and ${ }^{* * *}$ denote significance at $10 \%, 5 \%$, and $1 \%$ significance levels, respectively. 
Figure 1: NFA, international comparison in 2007

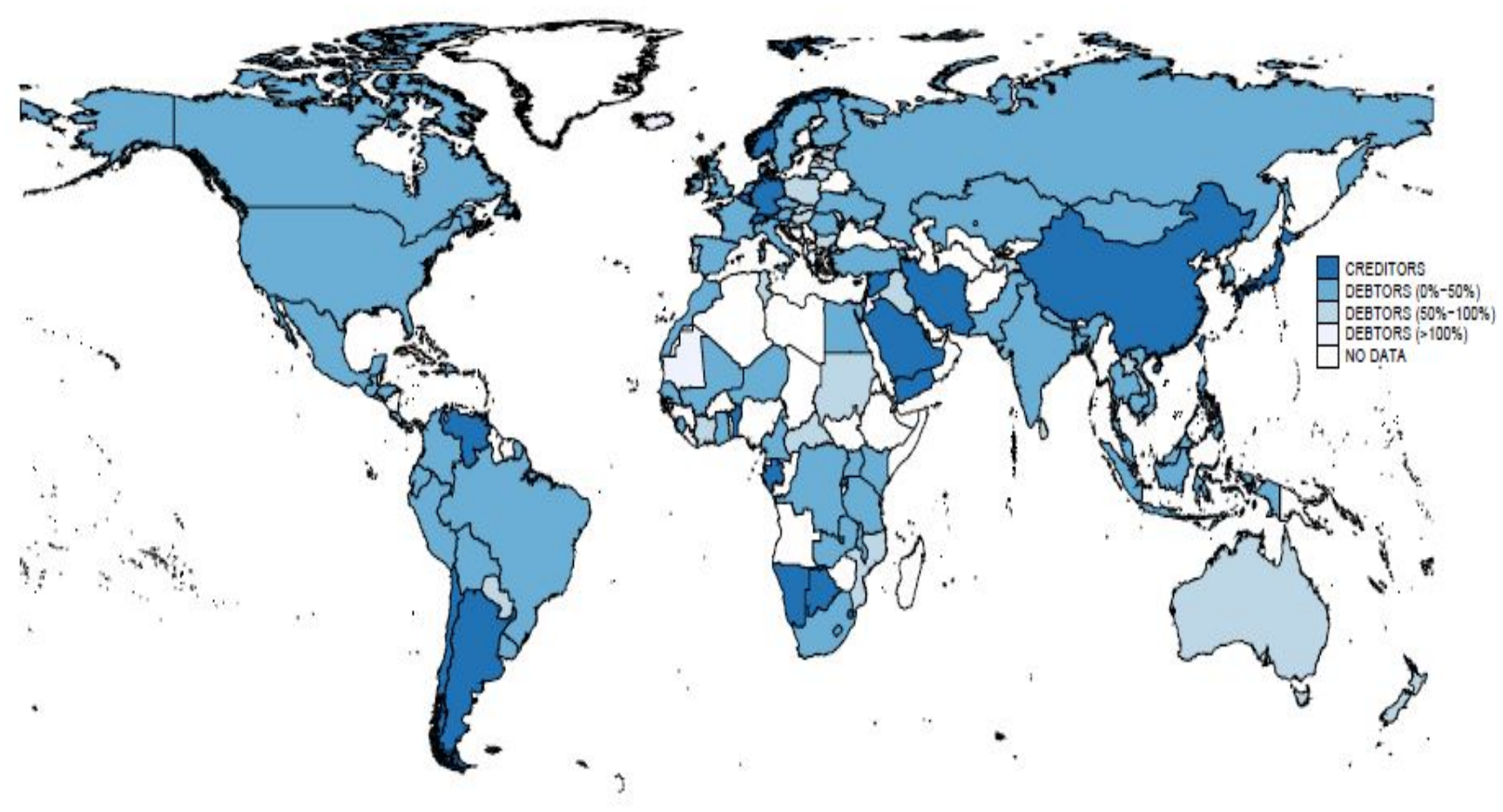


Figure 2: NFA (1983-2011)

a) NFA, groups of countries

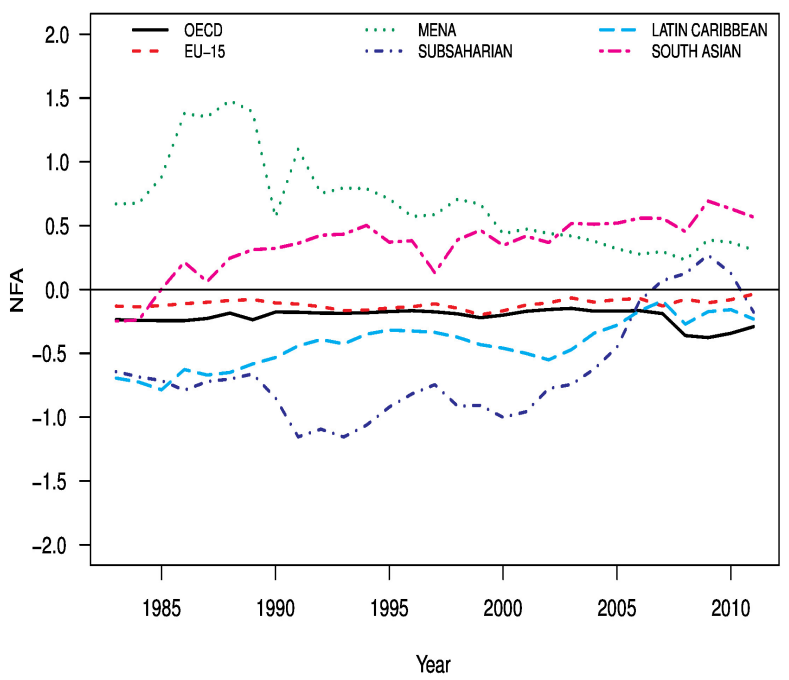

b) NFA by period, violin plots

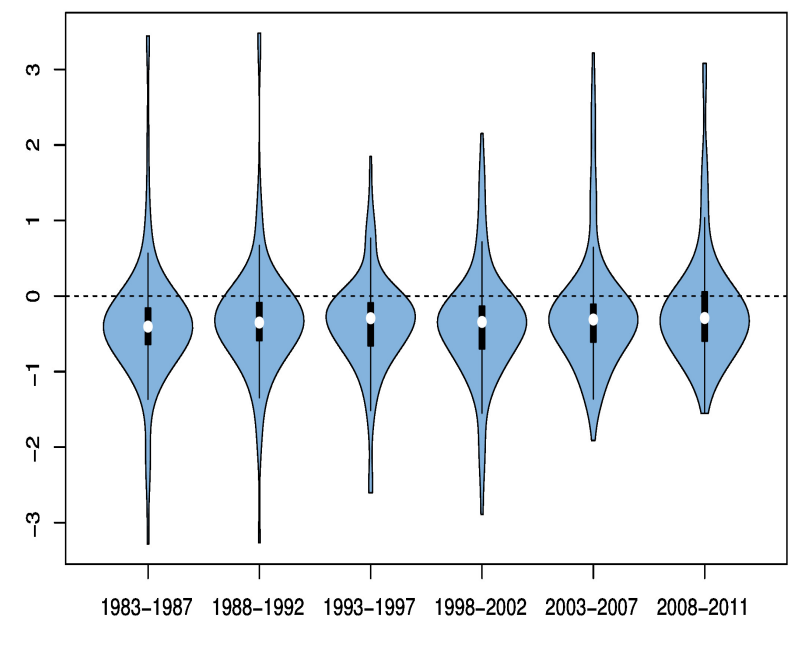

C) NFA and growth, 1983-2011

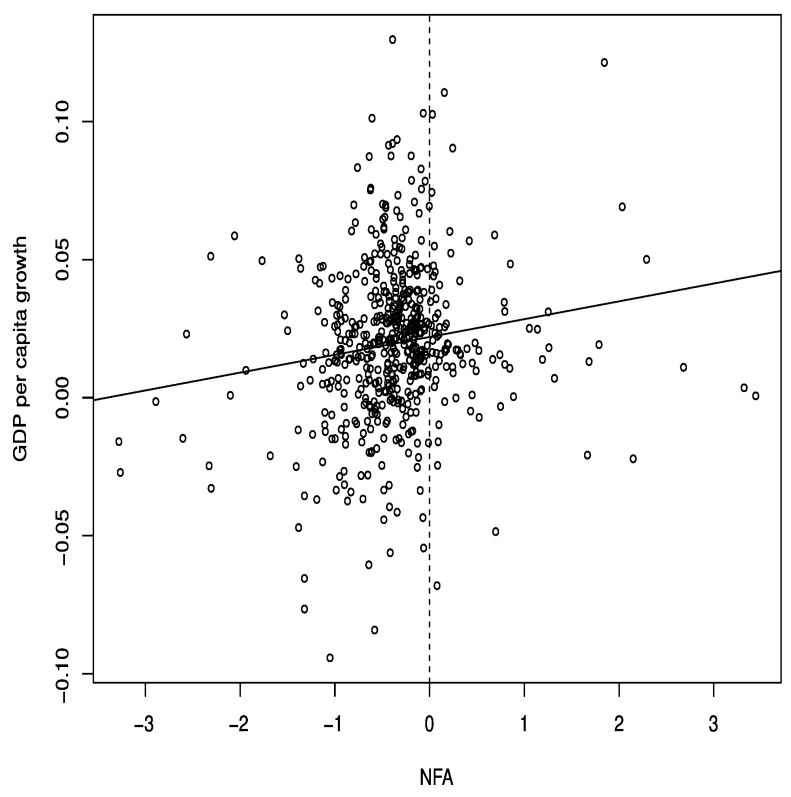

Notes: In the violin plots, the white bullet inside the box represents the median value and the black box contains $50 \%$ of the sample (first and third quartiles correspond to the bottom and the top of the box, respectively). The vertical bars represent observations beyond these limits and, finally, the kernel density overlaying the boxplot displays the probability mass at the different values of the represented variable. 
Figure 3: NFA, estimated coefficients

a) Kernel density for different models

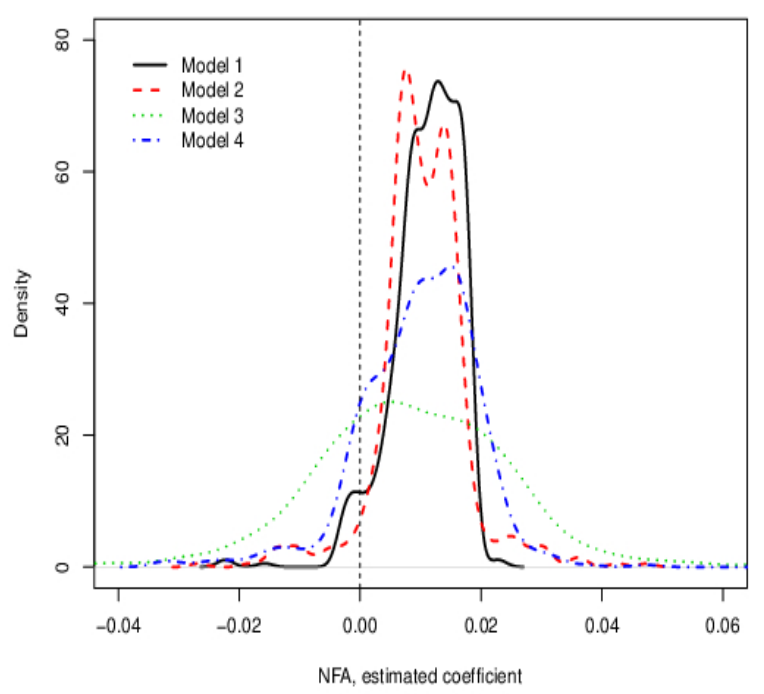

b) NFA, $45^{\circ}$ plot for estimates in Model 4

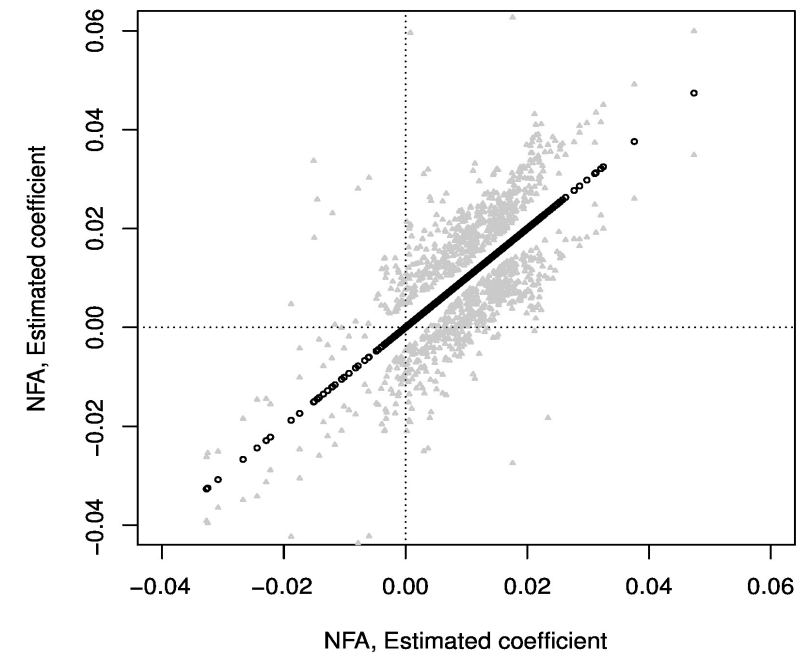


Figure 4: NFA, estimates for particular groups in Model 4
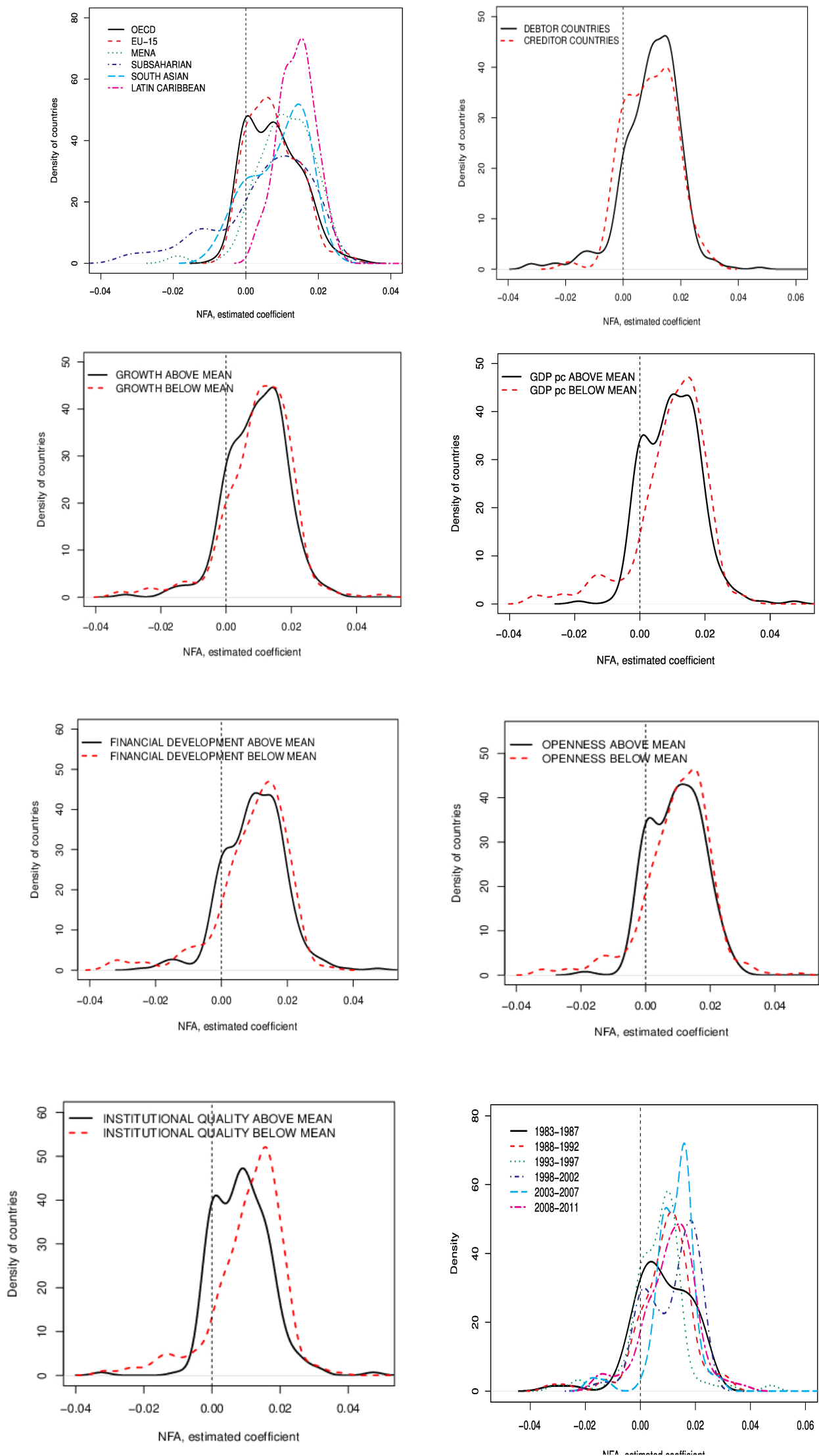


\section{Appendix A. List of countries}

Albania, Argentina, Armenia, Australia, Austria, Bahrain, Bangladesh, Belgium, Bolivia, Botswana, Brazil, Bulgaria, Cameroon, Canada, Chile, China, Colombia, Costa Rica, Côte d'Ivoire, Croatia, Cyprus, Czech Republic, D.R. Congo, Denmark, Dominican Republic, Ecuador, Egypt, El Salvador, Estonia, Finland, France, Gabon, Gambia, Germany, Ghana, Greece, Guatemala, Honduras, Hungary, Iceland, Iran, Iraq, Israel, Italy, Jamaica, Japan, Jordan, Kazakhstan, Kenya, Kuwait, Latvia, Liberia, Lithuania, Luxembourg, Malawi, Malaysia, Mali, Malta, Mexico, Mongolia, Morocco, Mozambique, Namibia, Netherlands, New Zealand, Niger, Norway, Pakistan, Panama, Paraguay, Peru, Philippines, Poland, Portugal, Qatar, Republic of Korea, Republic of Moldova, Romania, Russian Federation, Senegal, Serbia, Sierra Leone, Singapore, Slovakia, Slovenia, South Africa, Spain, Sri Lanka, Sudan, Sweden, Switzerland, Syrian Arab Republic, Thailand, Togo, Tunisia, Turkey, Uganda, Ukraine, United Kingdom, Tanzania, United States, Uruguay, Venezuela, Vietnam, Yemen, Zambia. 